\title{
Nitrogen-Doped Graphene and Its Iron-Based Composite as Efficient Electrocatalysts for Oxygen Reduction Reaction
}

\begin{tabular}{|r|l|}
\hline Journal: & ACS Nano \\
\hline Manuscript ID: & nn-2012-02674k.R3 \\
\hline Manuscript Type: & Article \\
\hline Date Submitted by the Author: & 08-Oct-2012 \\
\hline Complete List of Authors: & $\begin{array}{l}\text { Parvez, Khaled; Max Planck Institute for Polymer Research, } \\
\text { Yang, Shubin; Max Planck Institute for Polymer Research, } \\
\text { Hernandez, Yenny; Max Planck Institute for Polymer Research, } \\
\text { Winter, Andreas; University of Bielefeld, } \\
\text { Turchanin, Andrey; Universität Bielefeld, Physics of Supramolecular } \\
\text { Systems } \\
\text { Feng, Xinliang; Max-Planck Institute for Polymer Research, Synthetic } \\
\text { Chemistry } \\
\text { Mullen, Klaus; Max-Planck-Institute for Polymer Research, }\end{array}$ \\
\hline
\end{tabular}

SCHOLARONE ${ }^{\mathrm{m}}$

Manuscripts 


\title{
Nitrogen-Doped Graphene and Its Iron-Based
}

\section{Composite as Efficient Electrocatalysts for Oxygen}

\section{Reduction Reaction}

\author{
Khaled Parvez ${ }^{a}$, Shubin Yang ${ }^{a}$, Yenny Hernandez ${ }^{a}$, Andreas Winter ${ }^{b}$, Andrey Turchanin ${ }^{b}$, \\ Xinliang Feng ${ }^{*, a}$, Klaus Müllen ${ }^{* a}$
}

\author{
${ }^{a}$ Max Planck Institute for Polymer Research, Ackermannweg 10, D-55128 Mainz, Germany \\ ${ }^{b}$ Faculty of Physics, University of Bielefeld, Universitätsstr. 25, D-33615 Bielefeld, Germany. \\ *Address correspondence to muellen@mpip-mainz.mpg.de; feng@mpip-mainz.mpg.de
}

\begin{abstract}
The high cost of platinum based electrocatalysts for the oxygen reduction reaction (ORR) has hindered the practical application of fuel cells. Thanks to its unique chemical and structural properties, nitrogen doped graphene (NG) is among the most promising metal-free catalysts for replacing platinum. In this work, we have developed a cost effective synthesis of NG by using cyanamide as a nitrogen source and graphene oxide as a precursor, which led to high and controllable nitrogen contents ( $4.0 \%$ to $12.0 \%$ ) after pyrolysis. NG thermally treated at $900{ }^{\circ} \mathrm{C}$ shows a stable methanol cross-over effect, high current density $\left.(6.67 \mathrm{~mA} \mathrm{~cm})^{-2}\right)$ and durability $(\sim$
\end{abstract}


$87 \%$ after 10,000 cycles) when catalyzing ORR in alkaline solution. Further, iron (Fe) nanoparticles could be incorporated into NG with the aid of $\mathrm{Fe}(\mathrm{III})$ chloride in the synthetic process. This allows one to examine the influence of non-noble metals on the electrocatalytic performance. Remarkably, we found that NG supported with $5 \mathrm{wt} \%$ Fe nanoparticles displayed an excellent methanol cross over effect and high current density $\left(8.20 \mathrm{~mA} \mathrm{~cm}^{-2}\right)$ in an alkaline solution. Moreover, Fe incorporated NG showed almost four-electron transfer processes and superior stability both in alkaline $(\sim 94 \%)$ and acidic $(\sim 85 \%)$ solutions, which outperformed the platinum and NG-based catalysts.

KEYWORDS: graphene oxide, nitrogen doped graphene, iron coordination, oxygen reduction reaction, stability

The cathodic oxygen reduction reaction (ORR) plays a crucial role in electrochemical energy conversion in fuel cells. ${ }^{1}$ Platinum based materials have long been used as active catalysts for the ORR; however, these noble metal catalysts hinder widespread commercialization of fuel cells due to their high cost, sluggish electron transfer kinetics and limited supply. ${ }^{2-4}$ Moreover, during a long term electrochemical process, Pt-based catalysts generally suffer from surface oxide formation, particle dissolution and aggregation in alkaline electrolytes. ${ }^{5,6}$ Therefore, numerous efforts have been devoted to finding a suitable substitute for Pt-based catalysts including nitrogen doped carbon nanotubes, ${ }^{7-9}$ mesoporous graphitic arrays ${ }^{10}$ and non-precious transition metal catalysts (such as iron or cobalt coordinated to nitrogen doped carbons). ${ }^{11,12}$ The advantages of these alternative catalysts include low cost, excellent electrocatalytic activity, long durability and an environmentally benign character. In general, the transition metal catalysts can be synthesized by pyrolyzing precursors containing nitrogen, $\mathrm{Fe}$ or Co salts and macrocyclic compounds (like $\mathrm{Co}(\mathrm{II})$ or $\mathrm{Fe}(\mathrm{II})$ phthalocyanine or methoxyphenyl porphyrin) adsorbed on 
carbon black (CB). ${ }^{12-16}$ However, when the pyrolysis temperature is higher than $800{ }^{\circ} \mathrm{C}$, gasification of $\mathrm{CB}$ occurs, especially in the presence of $\mathrm{NH}_{3}$; this results in mass loss of carbon and consequently shortens the lifespan of these catalysts. ${ }^{17,18}$ Although the nature of nitrogen atoms in nitrogen doped carbon materials and the catalytically active sites in metal-nitrogencarbon (M-N-C) remain controversial, ${ }^{19,20}$ both quantum mechanical calculations ${ }^{21}$ and experimental investigations ${ }^{22}$ indicate that pyridinic and/or graphitic nitrogen moieties play an essential role in catalyzing the ORR. ${ }^{23}$

Graphene is a monolayer of carbon atoms arranged in a two-dimensional honeycomb network. It shows many intriguing properties such as high surface area, ${ }^{24}$ excellent electrical conductivity, ${ }^{25}$ and high thermal and chemical stability. ${ }^{26}$ Recently, nitrogen doped graphene (NG) has been shown to possess high electrocatalytic activity and long-term operational stability when catalyzing the ORR. ${ }^{27}$ The high surface area of NG results in many active sites for coordination with Fe or Co, which may lead to enhanced electrochemical performance and hence improve catalysis of the ORR. However, there are only a handful of studies on the preparation of NG including: treating graphene in ammonia at high temperature, ${ }^{28,29}$ using an ammonia plasma, ${ }^{30}$ and growth of $\mathrm{NG}$ on $\mathrm{Ni}$ substrates by chemical vapor deposition (CVD). ${ }^{27}$ All these processes require vacuum conditions and are difficult to scale up, which limits the practical use of NG. Therefore, an expeditious method to fabricate NG with controllable nitrogen moieties and high surface area is highly desirable.

Herein, we report the facile synthesis of NG by immobilizing graphitic carbon nitride $(\mathrm{CN})$ on graphene sheets to form a carbon nitride-graphene composite (CN-G). The CN-G composite is then subjected to thermal treatment, leading to the decomposition of $\mathrm{CN}$ and thereby introducing nitrogen moieties into graphene. In this way, NG sheets with nitrogen content from $4.0 \%$ to 
$12.0 \%$ can be obtained by controlling the pyrolysis temperature. Furthermore, NG infused with iron nanoparticles $(\mathrm{NG} / \mathrm{Fe})$ can be synthesized by the addition of iron salts $\left(\right.$ e.g. $\left.\mathrm{FeCl}_{3}\right)$ into the CN-G. We show that NG containing $5 \mathrm{wt} \% \mathrm{Fe}$ exhibits high electrocatalytic activity, low onset potential, excellent methanol cross over effect and long-term stability in oxygen reduction reactions in both acid and alkaline solutions. These traits represent clear advantages over commercially available Pt-based electrodes (30 wt\% Pt on Vulcan XC72).

\section{RESULTS AND DISCUSSION}

The synthesis of NG is illustrated in Figure 1. In the first step, graphene oxide (GO) was modified by a surfactant (sodium dodecylbenzenesulfonic acid, SDBS) to enhance the dispersion of GO in water. Afterwards, cyanamide $(4 \mathrm{~mL})$ was added dropwise into the $\mathrm{GO}(1 \mathrm{mg} / \mathrm{mL})$ solution (see Experimental section for details). The mixture was then heated to $100{ }^{\circ} \mathrm{C}$, continuously stirring, to remove water. Subsequently, the resultant solid powder was annealed at $550{ }^{\circ} \mathrm{C}$ under an argon flow for $4 \mathrm{~h}$ to trigger the thermal condensation of cyanamide, providing polymeric $\mathrm{CN}^{31}$ Further heat treatment of the $\mathrm{CN}-\mathrm{G}$ at 800,900 and $1000{ }^{\circ} \mathrm{C}$ gave rise to $\mathrm{CN}$ decomposition, and thereby generated NG. For simplicity, the samples are denoted as NG-800, NG-900 and NG-1000 respectively.

The morphology and structure of $\mathrm{CN}-\mathrm{G}$ were first investigated by transmission electron microscope (TEM) and scanning electron microscope (SEM). CN without incorporation of graphene sheets shows a typical slate like morphology, ${ }^{32}$ while $\mathrm{CN}-\mathrm{G}$ becomes crumpled (Figure S1) due to the adsorbed cyanamide on graphene, which undergoes polymerization under thermal treatment. As indicated in Figure 2a, graphene sheets were not distinctively visible in CN-G due to the thick layer of $\mathrm{CN}$ adsorbed on graphene surface. The XRD patterns of $\mathrm{CN}$, which stacks 
like graphite with a tri-s-triazine unit, feature two diffraction peaks at around $27.2^{\circ}$ and $13.1^{\circ} . .^{3}$ After the introduction of graphene, the unchanged XRD pattern suggests that graphene sheets are homogeneously distributed in $\mathrm{CN}$ without disrupting their solid state packing (Figure $2 \mathrm{~b}$ ).

Thermogravimetric analysis (TGA) of CN-G containing $5.0 \mathrm{wt} \%$ of graphene reveals that weight loss starts at around $600{ }^{\circ} \mathrm{C}$ (Figure S2), which can be assigned to the decomposition of CN. After treatment at $800{ }^{\circ} \mathrm{C}$, a total $\sim 95 \%$ weight loss of the composite suggests that only graphene remains. TEM images (Figure 2c and S3) of the NG-800, NG-900 and NG-1000 demonstrate transparent graphene sheets without the presence of any residual CN. A BrunauerEmmett-Teller (BET) surface area of $508 \mathrm{~m}^{2} \mathrm{~g}^{-1}$ for NG-900 (Figure S4) is obtained, which is higher than that of NG produced by other methods. ${ }^{33,34}$ In addition, a narrow pore-size distribution centered at about $3.1 \mathrm{~nm}$ and a total pore volume of $3.674 \mathrm{~cm}^{3} \mathrm{~g}^{-1}$, can be derived from the adsorption branch of the isotherms based on the Barrett-Joyner-Halenda (BJH) model.

To probe the chemical composition and content of nitrogen in NG, X-ray photoelectron spectroscopic (XPS) measurements were carried out on NG-800, NG-900 and NG-1000 (Figure $2 \mathrm{~d}$ and S5). As shown in Figure 2d, the survey spectra of NG samples reveals the presence of C, $\mathrm{O}$, and $\mathrm{N}$ and a nitrogen content of 12.0, 5.0, and 4.0\% in NG-800, NG-900 and NG-1000, respectively. This is consistent with the values determined by elemental analysis (Figure S5). Furthermore, absence of an S 2p peak at $165.0 \mathrm{eV}$ (Figure S5e) indicates that the surfactant (SDBS) was completely decomposed upon pyrolysis. The C 1s peaks for the NG samples (Figure S6a) center at approximately $284.6 \mathrm{eV}$ and are slightly asymmetric. This is a common effect for nitrogen doped carbon materials. ${ }^{35}$ The width of the C $1 \mathrm{~s}$ peaks become smaller as the pyrolysis temperature increases from 800 to $1000{ }^{\circ} \mathrm{C}$, suggesting enhanced graphitization at higher temperature. This result is further supported by the Raman spectrum (Figure S7); the G band 
becomes sharper and the intensity ratio of the $G$ to the $D$ band $\left(\mathrm{I}_{\mathrm{G}} / \mathrm{I}_{\mathrm{D}}\right)$ increases. ${ }^{36}$ Analysis of $\mathrm{N}$ 1s spectra reveals the presence of pyridinic- and graphitic- nitrogen corresponding to binding energies of 398.4 and $401.0 \mathrm{eV}$, respectively (Figure S6). ${ }^{23}$ In addition, the reaction between oxygen containing groups in GO and nitrogen species during the synthesis results in the formation of pyridinic $\mathrm{N}^{+}-\mathrm{O}^{-}$at $402.0-404.0 \mathrm{eV} .^{37}$ In $\mathrm{NG}-800$, pyridinic-N is more prevalent than graphitic-N, with content of $7.92 \%$ and $3.45 \%$, respectively (Figure 3a). Upon raising the pyrolysis temperature to 900 and $1000{ }^{\circ} \mathrm{C}$, the overall nitrogen content decreases dramatically. Interestingly, the pyridinic- $\mathrm{N}$ content largely drops to $1.47 \%$ at $900{ }^{\circ} \mathrm{C}$ and $1.14 \%$ at $1000{ }^{\circ} \mathrm{C}$, whereas the graphitic-N slowly decreases. However, the content of graphitic-N is higher than that of pyridinic-N at 900 and $1000{ }^{\circ} \mathrm{C}$. Furthermore, the ratio of graphitic-N to pyridinic-N content in NG-800, NG-900 and NG-1000 shows significant differences (i.e. 0.44, 1.73 and 1.66, respectively). A slight increase in pyridinic $\mathrm{N}^{+}-\mathrm{O}^{-}$is observed from NG-800 to NG-900, but remains unchanged in NG-1000. This type of nitrogen species does not significantly contribute to the ORR performance and is unstable under fuel cell operating conditions. ${ }^{38}$ Therefore, such different amounts of nitrogen bonding configurations in NG samples is expected to play a crucial role for the ORR electrocatalytic performances. ${ }^{39}$ The X-ray diffraction (XRD) of NG samples in Figure S8 shows a pronounced broad peak at $26.1^{\circ}$, attributable to the $\pi$-stacking of graphene sheets. ${ }^{27}$ The absence of a diffraction peak at $13.1^{\circ}$ also suggests that $\mathrm{CN}$ is successfully removed upon pyrolysis. The $\mathrm{N}$-doping may lead to an increased interlayer spacing in $\mathrm{NG}^{27}$ and as the nitrogen content decreases from NG-800 to NG-1000, the diffraction peaks become sharper.

The electrocatalytic activity of NG for the ORR was first examined - in a $0.1 \mathrm{M} \mathrm{KOH}$ solution saturated with argon or oxygen - by cyclic voltammetry $(\mathrm{CV})$ at a scan rate of $100 \mathrm{mV} \mathrm{s}^{-1}$. As 
shown in Figure 4a, featureless voltammetric currents within the potential range of -1.2 to $+0.2 \mathrm{~V}$ were observed for NG-900 in the argon saturated solution (dotted curve). In contrast, when the electrolyte was saturated with $\mathrm{O}_{2}$, a well-defined cathodic peak centered at $-0.16 \mathrm{~V}$ was detected, suggesting pronounced electrocatalytic activity of NG-900. A possible cross over effect in NG900 and $\mathrm{Pt} / \mathrm{C}$ against the electrooxidation of methanol in $\mathrm{O}_{2}$ saturated $0.1 \mathrm{M} \mathrm{KOH}$ in the presence of methanol $(3.0 \mathrm{M})$ was also detected. The $\mathrm{Pt} / \mathrm{C}$ shows a pair of peaks at $-0.15 \mathrm{~V}$ and $-0.08 \mathrm{~V}$ corresponding to methanol oxidation, whereas the cathodic peak for the ORR disappears (Figure 4b). In contrast, no noticeable change was seen in the oxygen reduction current on NG-900 under the same experimental conditions (Figure 4a), suggesting high selectivity and good stability of NG-900 for the ORR with respect to $\mathrm{Pt} / \mathrm{C}$.

To further evaluate the electrocatalytic activity of NG, both rotating ring disk electrodes (RRDE) and rotating disk electrodes (RDE) were employed. Figure 5a shows the steady state voltammograms for different NG samples loaded on a glassy carbon electrode in $\mathrm{O}_{2}$ saturated 0.1 $\mathrm{M} \mathrm{KOH}$. The corresponding ring current $\left(I_{\mathrm{R}}\right)$ for the oxidation of hydrogen peroxide ions $\left(\mathrm{HO}_{2}{ }^{-}\right)$ was measured with a Pt ring electrode with a potential of $0.50 \mathrm{~V}$. The electron transfer number per oxygen molecule involved in the ORR of the NG-800, NG-900 and NG-1000 electrode was calculated to be $3.35,3.70$ and 3.48 , respectively. The calculation used Eq. $1^{7}$ and a potential of $0.4 \mathrm{~V}$

$n=4 I_{\mathrm{D}} /\left(I_{\mathrm{D}}+I_{\mathrm{R}} / N\right)$

where $N=0.36$ is the collection efficiency, $I_{\mathrm{D}}$ is the disk current, and $I_{\mathrm{R}}$ is the ring current. The lower ring current of NG-900 compared to NG-800 and NG-1000 suggests that a lower amount of $\mathrm{HO}_{2}{ }^{-}$reached the ring electrode under increasing negative potentials. The onset potential of 
NG-900 was determined to be $-0.03 \mathrm{~V}$, which is close to that identified from CV measurements (-0.04 V, Figure 5a). Different from a Pt/C electrode, the NG-900 electrode showed an enhanced steady-state diffusion current over a large potential range.

The current density $\left(J_{\mathrm{K}}\right)$ of the NG samples was analyzed by RDE and calculated on the basis of the Koutecky-Levich equations [Eq. (2) - (4)]. ${ }^{10}$

$$
\begin{aligned}
& \frac{1}{J}=\frac{1}{J_{L}}+\frac{1}{J_{K}}=\frac{1}{B \omega^{1 / 2}}+\frac{1}{J_{K}} \\
& B=0.62 n F C_{0}\left(D_{0}\right)^{2 / 3} v^{-1 / 6} \\
& J_{K}=n F k C_{0}
\end{aligned}
$$

where $J$ is the measured current density, $J_{\mathrm{K}}$ and $J_{\mathrm{L}}$ are the kinetic and diffusion limiting current densities, $\omega$ is the angular velocity of the disk $(\omega=2 \pi N, N$ is the linear rotation speed), $n$ is the overall number of electrons transferred in the oxygen reduction, $F$ is the Faraday constant (96485 $\left.\mathrm{C} \mathrm{mol}^{-1}\right), C_{0}$ is the bulk concentration of $\mathrm{O}_{2}, v$ is the kinematic viscosity of the electrolyte, and $k$ is the electron transfer rate constant. The Koutckey-Levich plot of $J^{1} v s . \omega^{-1 / 2}$ at a potential of $0.40 \mathrm{~V}$ on the NG-900 electrode exhibited good linearity (Figure 5c). As shown in Figure 5d, the calculated $J_{\mathrm{K}}$ value of $6.67 \mathrm{~mA} \mathrm{~cm}{ }^{-2}$ at $-0.40 \mathrm{~V}$ is much higher than that of $\mathrm{Pt} / \mathrm{C}(4.76 \mathrm{~mA} \mathrm{~cm}$ at $-0.40 \mathrm{~V})$, and is comparable or even higher than previous reports on nitrogen doped graphene, CNTs, and other types of carbon materials. ${ }^{27,29,40,41}$ In association with the XPS and electrochemical results described for NG-800, NG-900 and NG-1000, the content of pyridinic-N among the different nitrogen species does not play a significant role in the performance of the ORR. In contrast, the electrochemical performance is dependent on the content of graphitic-N, 
for which a higher ratio of graphitic-N over pyridinic-N in NG-900 than NG-800 and NG-1000 might be responsible for the high catalytic performance. ${ }^{10}$

It has been reported that the pyridinic nitrogen enriched carbon material can be favorable for the fabrication of Fe-N-C based catalysts. ${ }^{42}$ Given that the present synthetic approach offers a high content of pyridinic- $\mathrm{N}$ sites in the $\mathrm{CN}-\mathrm{G}$ composite, one can expect that the introduction of $\mathrm{Fe}$ salts to $\mathrm{CN}-\mathrm{G}$ will lead to an incorporation of Fe nanoparticles into NG and provide efficient coordination between Fe and pyridinic-N. Towards this end, NG decorated with Fe nanoparticles was prepared by mixing $\mathrm{FeCl}_{3}$ with the precursors $\mathrm{GO}$ and cyanamide, followed by subsequent thermal treatment at $900{ }^{\circ} \mathrm{C}$ (Figure S9). The detailed procedure can be found in the experimental section. NG samples with different Fe content were prepared in this work and are denoted as $\mathrm{NG} / \mathrm{Fe}_{\mathrm{x}}($ where $\mathrm{x}=2.0,5.0,10.0$ and $15.0 \mathrm{wt} \%)$.

Figure 6a shows the XRD pattern of $\mathrm{NG} / \mathrm{Fe}_{5.0}$. The diffraction peak at $42.8^{\circ}$ is characteristic for Fe (110). In addition, HRTEM images display the presence of small (2-4 nm) crystalline Fe nanoparticles on NG. They also show a lattice d-spacing of $\sim 0.23 \mathrm{~nm}$, which is slightly higher than the standard value of $0.203 \mathrm{~nm}$ (JCPDS database) (Figure $6 \mathrm{~b}$ and $\mathrm{c}$ ). The larger d-spacing might be attributed to Fe nanoparticles incorporated into the nitrogen lattice, which enlarges the lattice constant. ${ }^{43}$ The presence of $\mathrm{N}$ and $\mathrm{Fe}$ in the composite can be further validated by the corresponding energy dispersive X-ray (EDX) analysis (Figure 6d). Increasing the Fe content to $15.0 \mathrm{wt} \%$ (i.e. $\mathrm{NG} / \mathrm{Fe}_{15.0}$ ) results in the agglomeration of $\sim 50 \mathrm{~nm}$ Fe nanoparticles. In contrast, no large nanoparticles were visible in $\mathrm{NG} / \mathrm{Fe}_{5.0}$ (Figure $\mathrm{S} 10 \mathrm{a}, \mathrm{b}$ ). The XPS survey spectra of $\mathrm{NG} / \mathrm{Fe}_{5.0}$ shows the presence of $\mathrm{Fe} 2 \mathrm{p}$ and $\mathrm{Fe} 3 \mathrm{p}$, in addition to $\mathrm{N} 1 \mathrm{~s}, \mathrm{C} 1 \mathrm{~s}$ and $\mathrm{O} 1 \mathrm{~s}$ peaks (Figure S11). Unfortunately, the Fe $3 p$ peak $(\sim 52-56 \mathrm{eV})$ is too weak to determine the valence state of Fe. 
The catalytic properties of $\mathrm{NG} / \mathrm{Fe}_{\mathrm{x}}$ samples were first assessed with cyclic voltammetry in a 0.1 $\mathrm{M} \mathrm{KOH}$ solution. The $\mathrm{NG} / \mathrm{Fe}_{5.0}$ shows a featureless voltammetric current within the potential range of -1.2 to $+0.2 \mathrm{~V}$ in an Ar-saturated alkaline solution (Figure S12). Saturating the electrolyte with $\mathrm{O}_{2}$ results in a well-defined cathodic peak at $\sim 0.20$ V. Similar to NG-900, $\mathrm{NG} / \mathrm{Fe}_{5.0}$ did not show any change in the oxygen reduction current in an $\mathrm{O}_{2}$ saturated alkaline solution in the presence of $3.0 \mathrm{M}$ methanol, making the catalyst very stable against crossover effects. However, two additional peaks were observed at -0.61 and $-0.93 \mathrm{~V}$, which are associated with the redox reaction of the iron nanoparticles. ${ }^{7}$ Figure 7 a shows the RRDE polarization curves of $\mathrm{NG} / \mathrm{Fe}_{\mathrm{x}}$ composites supported on a glassy carbon electrode in $\mathrm{O}_{2}$ saturated $0.1 \mathrm{M} \mathrm{KOH}$. The electron transfer number for $\mathrm{NG} / \mathrm{Fe}_{\mathrm{x}}$ samples, at the potential of $-0.4 \mathrm{~V}$, was calculated to be 3.79, 3.91, 3.80 and 3.79 for the $\mathrm{NG} / \mathrm{Fe}_{2.0}, \mathrm{NG} / \mathrm{Fe}_{5.0}, \mathrm{NG} / \mathrm{Fe}_{10.0}$ and $\mathrm{NG} / \mathrm{Fe}_{15.0}$, respectively. All samples of NG loaded with Fe nanoparticles greatly enhanced the electrochemical performance leading to four electron transfer processes in the ORR. Although the onset potential for the ORR at the $\mathrm{NG} / \mathrm{Fe}_{5.0}$ electrode was similar (i.e. $-0.04 \mathrm{~V}$ ) to that of $\mathrm{Pt} / \mathrm{C}$, the reduction current was significantly higher (Figure S12). As shown in Figure $7 b$, the calculated current density $\left(J_{\mathrm{K}}\right)$ value of $\mathrm{NG} / \mathrm{Fe}_{2.0}, \mathrm{NG} / \mathrm{Fe}_{5.0}, \mathrm{NG} / \mathrm{Fe}_{10.0}$ and $\mathrm{NG} / \mathrm{Fe}_{15.0}$ is $3.57,8.20,7.69$ and $5.26 \mathrm{~mA} \mathrm{~cm}{ }^{-2}$, respectively. This result suggests that increasing the Fe content leads to an increase in the concentration of active catalytic sites until all pyridinic-N is coordinated (at $5.0 \mathrm{wt} \%$ ). ${ }^{44}$ Increasing the Fe content from $5.0 \mathrm{wt} \%$ to 10.0 and $15.0 \mathrm{wt} \%$ produces uncoordinated metal particles (Figure S10) which do not provide additional catalytic sites. ${ }^{45}$ Therefore, no enhancement of the current density or electron transfer number was observed for $\mathrm{NG} / \mathrm{Fe}_{10.0}$ and $\mathrm{NG} / \mathrm{Fe}_{15.0}$. It is remarkable to note that $\mathrm{NG} / \mathrm{Fe}_{5.0}$ has a current density almost two times higher than $\mathrm{Pt} / \mathrm{C}\left(4.76 \mathrm{~mA} \mathrm{~cm}^{-2}\right)$. This suggests that incorporating Fe nanoparticles into NG provides a 
synergistic coupling between $\mathrm{Fe}$ and $\mathrm{NG}$ that results in an outstanding electrocatalytic performance compared to $\mathrm{Pt} / \mathrm{C}$ and NG-900.

\begin{abstract}
Another set of $\mathrm{NG} / \mathrm{Fe}_{\mathrm{x}}$ samples were prepared by treatment at $800{ }^{\circ} \mathrm{C}$ and $1000{ }^{\circ} \mathrm{C}$. Figure $\mathrm{S} 14$ shows the summarized results of electron transfer number and $J_{\mathrm{K}}$ values obtained from both RRDE and RDE. The catalytic performance of $\mathrm{NG} / \mathrm{Fe}_{5.0}$ (at $800{ }^{\circ} \mathrm{C}$ ) is lower than that of the samples prepared at $900{ }^{\circ} \mathrm{C}$ (Figure S13a). Surprisingly, $\mathrm{NG} / \mathrm{Fe}_{5.0}$ prepared at $1000{ }^{\circ} \mathrm{C}$ (Figure $\mathrm{S} 14 \mathrm{~b})$ showed a higher electron transfer number and $J_{\mathrm{K}}$ than samples prepared at $800{ }^{\circ} \mathrm{C}$ and slightly lower values than $\mathrm{NG} / \mathrm{Fe}_{5.0}$ prepared at $900{ }^{\circ} \mathrm{C}$. This result suggests that the oxygen reduction reaction rate increases with heat-treatment temperature of the catalysts, reaching a plateau at $<1000{ }^{\circ} \mathrm{C} .{ }^{46,47}$ Thus, it can be concluded that the higher content of pyridinic-N alone (by lower temperature treatment) does not necessarily result in high catalytic performance. In addition, the temperature for catalyst preparation plays an important role in the synergistic coupling between Fe and nitrogen components in the composites.
\end{abstract}

Furthermore, $\mathrm{NG} / \mathrm{Fe}_{\mathrm{x}}$ composites also showed high ORR activity in acidic solution. Both RRDE and RDE measurements were carried out in $0.5 \mathrm{M} \mathrm{H}_{2} \mathrm{SO}_{4}$ solution (Figure $7 \mathrm{c}$ and d). All the NG samples containing Fe again showed higher electron transfer numbers compared to NG samples at the potential of $0.2 \mathrm{~V}$ vs. $\mathrm{Ag} / \mathrm{AgCl}$. At $1600 \mathrm{rpm}$, the $\mathrm{NG} / \mathrm{Fe}_{5.0}$ showed a maximum $J_{\mathrm{K}}$ of about $1.47 \mathrm{mAcm}^{-2}$ with almost four-electron transfer $(\mathrm{n}=3.82)$ processes and the lowest onset potential $(0.47 \mathrm{~V}$ vs. $\mathrm{Ag} / \mathrm{AgCl})$ of all tested electrodes. The catalytic activity order of the $\mathrm{NG} / \mathrm{Fe}_{\mathrm{x}}$ catalysts in acidic medium was the same as that in alkaline medium, but they showed much higher current density in the alkaline solution. 
To examine the influence of any un-coordinated Fe nanoparticles (i.e. Fe residues) in the NG/Fe composites on the electrocatalytic performance, $\mathrm{NG} / \mathrm{Fe}_{5.0}$ was first treated in $2 \mathrm{M} \mathrm{H}_{2} \mathrm{SO}_{4}$ at $80{ }^{\circ} \mathrm{C}$ for $3 \mathrm{~h}$ and again subjected to ORR measurements in alkaline and acidic solutions. Remarkably, the acid treated $\mathrm{NG} / \mathrm{Fe}_{5.0}$ showed almost same ORR catalytic activity and a similar onset potential, electron transfer number, and current density in both acidic and alkaline media (Figure 8). This result shows that Fe residues do not significantly contribute to the ORR performance.

The stability of NG-900, NG/Fe 5.0 , and Pt/C electrodes toward the ORR was first examined by continuous potential cycling between +0.2 to $-1.2 \mathrm{~V}$ in $\mathrm{O}_{2}$ saturated $0.1 \mathrm{M} \mathrm{KOH}$ for 10,000 cycles (Figure S13). As indicated in Figure S15a, the deterioration of the Pt/C electrode resulted in a $58 \%$ drop in current density. In contrast, $\mathrm{NG}-900$ and $\mathrm{NG} / \mathrm{Fe}_{5.0}$ electrodes showed only a slight decay of current density $-\sim 13 \%$ and $\sim 6 \%$ at $-0.15 \mathrm{~V}$, respectively (Figure S15b and c). The voltammetric response of the two electrodes also remained unchanged after the continuous potential cycles. In addition, the $\mathrm{NG} / \mathrm{Fe}_{5.0}$ showed only $\sim 15 \%$ decay in the current density (at $0.38 \mathrm{~V}$ ) in acidic medium after 10,000 cycles (Figure $\mathrm{S} 12 \mathrm{~d}$ ). These results show that $\mathrm{NG} / \mathrm{Fe}_{5.0}$ exhibited superior durability over $\mathrm{Pt} / \mathrm{C}$ based catalysts.

\section{CONCLUSION}

In summary, we report a facile and scalable method to prepare NG to catalyze the ORR in a fuel cell. The prominent features of synthesized the NG include high nitrogen content, high surface area, high electrocatalytic activity, and superior durability. The incorporation of Fe nanoparticles into the NG results in significantly enhanced performance of graphene based catalysts. These $\mathrm{NG} / \mathrm{F}_{\mathrm{x}}$ catalysts feature the almost four electron transfer processes, high current density, and superb stability. They also outperform Pt/C towards ORR in both in acidic and alkaline media. In 
addition to their promising application as fuel cell catalysts, we anticipate that NG with and without metal nanoparticles will provide broad applications in the field of lithium ion batteries, sensors, field-effect transistors and supercapacitors.

\section{Experimental Section}

Synthesis of $G O, N G$ and $N G / F e_{x}$ composites: Graphite oxide was prepared from natural graphite by a modified Hummers' method. ${ }^{48}$ Graphene-carbon nitride (G-CN) composites were prepared by electrostatic interaction between anionic surfactant modified graphene oxide (GO) and cyanamide precursor for synthesizing carbon nitride $(\mathrm{CN})$. In a typical synthesis, $0.1 \mathrm{~g}$ of the surfactant sodium dodecylbenzene sulfonic acid (SDBS) was mixed with $100 \mathrm{~mL}$ of GO dispersion $(1 \mathrm{mg} / \mathrm{mL})$ in water and sonicated for $30 \mathrm{~min}$. Then, $4 \mathrm{~mL}$ of cyanamide solution $(50$ $\mathrm{wt} \%$ in water) was added dropwise. The mixture was then stirred continuously and heated at 100 ${ }^{\circ} \mathrm{C}$ to remove water. The resulting solid was calcined in two different steps. In the first step, the solid products were heated to $550{ }^{\circ} \mathrm{C}$ at a rate of $2{ }^{\circ} \mathrm{C} / \mathrm{min}$ and tempered at this temperature for another $4 \mathrm{~h}$ to form $\mathrm{CN}{ }^{31}$ To prepare NG, the resulting $\mathrm{CN}-\mathrm{G}$ composites were further heated to 800,900 and $1000^{\circ} \mathrm{C}$. All the sample annealing and cooling processes were carried out under argon flow. For comparison, undoped and reduced GO (rGO) was also prepared by pyrolyzing pure GO under the same annealing processes.

Composites of NG with iron nanoparticles were synthesized by adding the desired amount (i.e. 2, $5,10$ and $15 \mathrm{mg})$ of $\mathrm{FeCl}_{3}$ to $100 \mathrm{mg}$ of $\mathrm{GO}$ solution $(1 \mathrm{mg} / \mathrm{mL})$ and sonicating the mixture for 1 h. The content of Fe (i.e. 2.0, 5.0, 10.0 and $15.0 \mathrm{wt} \%$ ) in the composites was calculated with respect to the total mass of GO into the solution. Then $4 \mathrm{~mL}$ of cyanamide solution was added dropwise. The reaction mixture was then heated at $100{ }^{\circ} \mathrm{C}$ with continuous stirring to remove 
water. The resulting solid was then calcined at $550{ }^{\circ} \mathrm{C}$ for $4 \mathrm{~h}$ to form $\mathrm{CN}$ and then pyrolysed separately at 800,900 and $1000{ }^{\circ} \mathrm{C}$ for $1 \mathrm{hr}$ to decompose the $\mathrm{CN}$. All the annealing processes were carried under argon atmosphere.

Characterization: The morphology and microstructures of the samples were investigated by HRTEM (Philips Tecnai F20), TGA (Mettler TG 50), XRD (Bruker D4 X-ray scattering system with $\mathrm{Ni}$ filtered $\mathrm{Cu} \mathrm{K} \alpha$ radiation). Raman spectra were recorded with a Bruker RFS 100/S spectrometer. Nitrogen sorption isotherms and BET surface areas were measured at $77 \mathrm{~K}$ with a Micromeritcs Tristar 3000 analyzer (USA). The chemical composition was analyzed by XPS with an Omicron Multiprobe spectrometer using $\mathrm{Al} \mathrm{K}_{\alpha}$ radiation. For these measurements $\mathrm{CN}-\mathrm{G}$ composites were ultrasonicated in ethanol and then casted and dried at ambient conditions on $\mathrm{Au}$ substrates (30 nm Au films thermally evaporated on Cr-primed Si wafers, Georg-Albert PVDCoatings). XPS binding energies were referenced to the $\mathrm{Au} 4 \mathrm{f}_{7 / 2}$ peak $(84.0 \mathrm{eV})$. Elemental chemical ratios in $\mathrm{CN}-\mathrm{G}$ composites were calculated from areas of the $\mathrm{XP}$ peaks. The calculations assumed a homogeneous distribution of elements in the samples and normalized the peak areas with Scofield sensitivity factors and electron attenuations lengths evaluated from the Laibinis expression. For the analysis of N1s spectra a Shirley background subtraction procedure was employed and symmetric Voigt functions (90\% of Gaussian character) were used for fitting. All fits were self-consistent.

Electrocatalytic activity evaluation: The ORR activity and four-electron selectivity of the nitrogen doped graphene samples were evaluated using a rotating disk electrode (RDE) and a rotating ring disk electrode (RRDE), respectively. RDE/RRDE measurements were performed using CHI Electrochemical Station (Model 760D) in a conventional three-electrode electrochemical cell. Platinum wire and an $\mathrm{Ag} / \mathrm{AgCl}, \mathrm{KCl}(3 \mathrm{M})$ electrode were used as the 
counter and reference electrode, respectively. The preparation of a glassy carbon working electrode ( $5 \mathrm{~mm}$ in diameter) is as follows: prior to use the working electrode was polished mechanically with $0.05 \mu \mathrm{m}$ alumina slurry to obtain a mirror like surface, then washed with MillQ water and acetone and allowed to dry. $1 \mathrm{mg}$ of the prepared NG sample was dissolved in a 1 $\mathrm{mL}$ solvent mixture of Nafion $(5 \mathrm{wt} \%)$ and water $(\mathrm{V}: \mathrm{V}$ ratio $=1: 9)$ using sonication. For comparison, a commercially available catalyst of $30 \mathrm{wt} \% \mathrm{Pt}$ supported on black carbon (fuel cell grade) was used and a $1 \mathrm{mg} / \mathrm{mL} \mathrm{Pt} / \mathrm{C}$ suspension was prepared according to the same procedure described above. The electrodes were allowed to dry at room temperature before the measurement. This leads to a catalyst (NG samples or Pt/C) loading of $50.91 \mu \mathrm{g} \mathrm{cm}^{-2}$.

The RRDE experiments were carried out in an $\mathrm{O}_{2}$ saturated $0.1 \mathrm{M} \mathrm{KOH}$ solution. The potential was varied from +0.2 to $-1.2 \mathrm{~V}$ at a potential sweep of $10 \mathrm{mVs}^{-1}$; the ring potential was set to 0.5 V. First, the potential range was cyclically scanned between- 1.2 and $+0.2 \mathrm{~V}$ at a scan rate of 100 $\mathrm{mV} \mathrm{s}^{-1}$ at ambient temperature after purging with $\mathrm{O}_{2}$ or Ar gas for $15 \mathrm{~min}$. Then the RRDE experiments were performed. RRDE experiments in acidic conditions were performed in an $\mathrm{O}_{2}$ saturated $0.5 \mathrm{M} \mathrm{H}_{2} \mathrm{SO}_{4}$ solution within the potential range of +0.8 to $-0.2 \mathrm{~V}$ at a potential sweep of $10 \mathrm{mVs}^{-1}$ and a ring potential of $1.0 \mathrm{~V}$.

Acknowledgement: This work was financially supported by the Max Planck Society through the program ENERCHEM, DFG Priority Program SPP 1459, BMBF LiBZ Project, BMBF Graphenoid project, ESF Project GOSPEL (Ref Nr: 09-EuroGRAPHENE-FP-001), EU Project GENIUS and ERC grant on NANOGRAPH.

Supporting Information Available: SEM, TGA of CN and CN-G samples; HRTEM, BET, XPS of C1s, N1s and S 2p spectra, Raman characterizations of NG; synthetic scheme, TEM, XPS 
spectra and electrochemical characterizations of $\mathrm{NG} / \mathrm{Fe}_{\mathrm{x}}$ samples. This material is available free of charge via the Internet at http://pubs.acs.org.

\section{REFERENCES}

1. Steele, B.C.H.; Heinzel, A. Materials for Fuel-Cell Technologies. Nature 2001, 414, 345-352.

2. Shao, Y.Y.; Liu, J.; Wang, Y.; Lin, Y.H. Novel Catalyst Support Materials for PEM Fuel Cells: Current Status and Future Prospects. J. Mater Chem. 2009, 19, 46-59.

3. Chen, W.; Chen, S.W. Oxygen Electroreduction Catalyzed by Gold Nanoclusters: Strong Core Size Effects. Angew. Chem. Int. Ed. 2009, 48, 4386-4389.

4. Chen, W.; Kim, J.M.; Sun, S.H.; Chen, S.W. Electrocatalytic Reduction of Oxygen by FePt Alloy Nanoparticles. J. Phys. Chem. C 2008, 112, 3891-3898.

5. Gewirth, A.A.; Thorum, M.S. Electroreduction of Dioxygen for Fuel-Cell Applications: Materials and Challenges. Inorg. Chem. 2010, 49, 3557-3566.

6. Jin, W.; Du, H.; Zheng, S.L.; Xu, H.B.; Zhang, Y. Comparison of the Oxygen Reduction Reaction between $\mathrm{NaOH}$ and $\mathrm{KOH}$ Solutions on a Pt electrode: The Electrolyte-Dependent Effect. J. Phys. Chem. B 2010, 114, 6542-6548.

7. Gong, K.P.; Du, F.; Xia, Z.H.; Durstock, M.; Dai, L.M. Nitrogen-Doped Carbon Nanootube Arrays with High Electrocatalytic Activity for Oxygen Reduction Reaction. Science 2009, $323,760-764$.

8. Yu, D.; Zhang, Q.; Dai, L. Highly Efficient Metal-Free Growth of Nitrogen-Doped SingleWalled Carbon Nanotubes on Plasma-Etched Substrates for Oxygen Reduction. J. Am. Chem. Soc. 2010, 132, 15127-15129. 
9. Feng, L.; Yan, Y.; Chen, Y.; Wang, L. Nitrogen-Doped Carbon Nanotubes as Efficient and Durable Metal-free Cathodic Catalysts for Oxygen Reduction in Microbial Fuel Cells. Energy Environ. Sci. 2011, 4, 1892-1899.

10. Liu, R.; Wu, D.Q.; Feng, X.; Müllen, K. Nitrogen-Doped Ordered Mesoporous Graphitic Arrays with High Electrocatalytic Activity for Oxygen Reduction. Angew. Chem Int. Ed. 2010, 49, 2565-2569.

11. Lefèvre, M.; Proitetti, E.; Jaouen, F.; Dodelet, J.P. Iron-Based Catalysts with Improved Oxygen Reduction Activity in Polymer Electrolyte Fuel Cells. Science 2009, 324, 71-74.

12. Wu, G.; More, K.L.; Johnston, C.M.; Zelenay, P. High-Performance Electrocatalysts for Oxygen Reduction Derived from Polyaniline, Iron, and Cobalt. Science 2011, 332, 443-447.

13. Jasinski, R. A New Fuel Cell Cathode Catalyst. Nature 1964, 201, 1212-1213.

14. Gupta, S.; Tyrk, D.; Bae, I.; Aldred, W.; Yeager, E. Heat-Treated Polyacrylonitrile-Based Catalysts for Oxygen electroreduction. J. Appl. Electrochem. 1989, 19, 19-27.

15. Schulenburg, H.; Stankov, S.; Schünemann, V.; Tributsch, H. Catalysts for Oxygen Reduction From Heat-Treated Iron (III) tetramethoxyphenylporphyrin chloride: Structure and Stability of Active Sites. J. Phys. Chem. B 2003, 107, 9034-9041.

16. Li, W.; Yu, A.; Higgins, D.C.; Llanos, B.G.; Chem, Z. Biologcally Inspired Highly Durable Iron Phthalocyanine Catalysts for Oxygen Reduction Reaction in Polymer Electrolyte Membrane Fuel Cells. J. Am. Chem. Soc. 2010, 132, 17056-17058.

17. Jaouen, F.; Lafèvre, M.; Dodelet, J.P.; Cai, M. Heat-treated Fe/N/C Catalysts for O2 Electroreduction: Are Active Sites Hosted in Micropores? J. Phys. Chem. B 2006, 110, 55535558. 
18. Lafèvre, M.; Dodelet, J.P. Fe-Based Electrocatalysts Made with Microporous Pristine Carbon Black Support for the Reduction of Oxygen in PEM Fuel Cells. Elecrochim. Acta 2008, 53, $8269-8276$.

19. Shao, Y.Y.; Sui, J.H.; Yin, G.P.; Gao, Y.Z. Nitrogen-Doped Carbon Nanostructures and Their Composites as Catalytic Materials for Proton Exchange Membrane Fuel Cells. Appl. Catal. B 2008, 79, 89-99.

20. Thorum, M.S.; Hankett, J.M.; Gewirth, A.A. Poisoning the Oxygen Reduction Reaction on Carbon-Supported $\mathrm{Fe}$ and $\mathrm{Cu}$ Electrocatalysts: Evidence for Metal-Centered Activity. J. Phys. Chem. Lett. 2011, 2, 295-298.

21. Ikeda, T.; Boero, M.; Haung, S.F.; Terakura, K.; Oshima, M.; Ozaki, J. Carbon Alloy Catalysts: Active Sites for Oxygen Reduction Reaction. J. Phys. Chem. C 2008, 112, 1470614709.

22. Liu, G.; Li, X.G.; Ganesan, P.; Popov, B.N. Studies of Oxygen Reduction Reaction Active Sites and Stability of Nitrogen-Modified Carbon Composites for PEM Fuel Cells. Electrochim. Acta 2010, 55, 2853-2858.

23. Yang, S.; Feng, X.; Wang, X.; Müllen, K. Graphene-Based Carbon Nitride Nanosheets as Efficient Metal-Free Electrocatalysts for Oxygen Reduction Reactions. Angew. Chem. Int. Ed. 2011, 50, 5339-5343.

24.Stoller, M.D.; Park, S.J.; Zhu, Y.W.; An, J.H.; Rouff, R.S. Graphene-Based Ultracapacitors. Nano Lett. 2008, 8, 3498-3502.

25. Yang, S.; Feng, X.; Ivanovici, S.; Müllen, K. Fabrication of Graphene-Encapsulated Oxide Nanoparticles: Towards High-Performance Anode Materials for Lithium Storage. Angew. Chem. Int. Ed. 2010, 49, 8408-8411. 
26. Balandin, A.A.; Ghosh, S.; Bao, W.Z.; Calizo, I.; Teweldebrhan, D.; Miao, F.; Lau, C.N. Superior Thermal Conductivity of Single-Layer Graphene. Nano Lett. 2008, 8, 902-907.

27. Qu, L.; Liu, Y.; Baek, J.-B.; Dai, L. Nitrogen-Doped Graphene as Efficient Metal-Free Electrocatalysts for Oxygen Reduction Reaction in Fuel Cells. ACS Nano 2010, 4, 1321-1326. 28. Li, X.; Wang, H.; Robinson, J.T.; Sanchez, H.; Diankov, G.; Dai, H. Simultaneous Nitrogen Doping and Reduction of Graphene Oxide. J. Am. Chem. Soc. 2009, 131, 15939-15944.

29. Geng, D.; Chen, Y.; Chen, Y.; Li, Y.; Li, R.; Sun, X.; Ye, S.; Knights, S. High OxygenReduction Activity and Durability of Nitrogen-Doped Graphene. Energy Environ. Sci. 2011, $4,760-764$.

30. Lin, Y.-C.; Lin, C.-Y.; Chiu, P.-W. Controllable Graphene N-Doping with Ammonia Plasma. Appl. Phys. Lett. 2010, 96, 133110.

31. Wang, X.C.; Maeda, K.; Thomas, A.; Takanabe, K.; Xin, G.; Carlsson, J.M.; Domen, K.; Antonietti, M. A Metal-Free Polymeric Photocatalysts for Hydrogen Production From Water Under Visible Light. Nature Mater. 2009, 8, 76-80.

32. Zhang, Y.; Thomas, A.; Antonietti, M.; Wang, X. Activation of Carbon Nitride Solids by Protonation: Morphology Changes, Enhances Ionic Conductivity and Photoreduction Experiments. J. Am. Chem. Soc. 2009, 131, 50-51.

33. Lee, K.R.; Lee, K.U.; Lee, J.W.; Ahn, B.T.; Woo, S.I. Electrochemical Oxygen Reduction on Nitrogen Doped Graphene Sheets in Acid Media. Electrochem. Commun. 2010, 12, 10521055.

34. Sheng, Z.H.; Shao, L.; Chen, J.J.; Bao, W.J.; Wang, F.B.; Xia, X.H. Catalyst-Free Synthesis of Nitrogen-Doped Graphene via Thermal Annealing Graphite Oxide with Melamine and Its excellent Electrocatalysis. ACS Nano 2011, 5, 4350-4358. 
35. Côtć, R.; Lalandc, G.; Guay, D.; Dodclct, J.P.; Dćnćs, G. Influence of Nitrogen-Containing Precursors on the Electrocatalytic Activity of Heat-Treated $\mathrm{Fe}(\mathrm{OH})_{2}$ on Carbon Black for $\mathrm{O}_{2}$ Reduction. J. Electrochem. Soc. 1998, 145, 2411-2418.

36. Kim, T.W.; Park, I.S.; Ryoo, R.; A Synthetic Route to Ordered Mesoporous Carbon with Graphitic Pore Walls. Angew. Chem. Int. Ed. 2003, 42, 4375-4379.

37. Chen, Z.; Higgins, D.; Tao, H.; Hsu, R.S.; Chen, Z. Highly Active Nitrogen-Doped Carbon Nanotubes for Oxygen Reduction Reaction in Fuel Cell Application. J. Phys. Chem. C 2009, $113,21008-21013$.

38. Liu, G.; Li, X.; Lee, J.W. ; Popov, B.N. A Review of the Development of Nitrogen-Modified Carbon-Based Catalysts for Oxygen Reduction as USC. Catal. Sci. Technol. 2011, 1, 207217.

39. Rao, C.V.; Caberea, C.R.; Ishikawa, Y. In Search of the Active Site in Nitrogen-Doped Carbon Nanotube Electrodes for the Oxygen Reduction Reaction. J. Phys. Chem. Lett. 2010, $1,2622-2627$.

40. Jeon, I.Y.; Yu, D.; Bae, S.Y.; Choi, H.J.; Chang, D.W.; Dai, L.; Baek, J.B. Formation of Large-Area Nitrogen-Doped Graphene Film Prepared from Simple Solution Casting of EdgeSelectively Functionalized Graphite and Its Electrocatalytic Activity. Chem. Mater. 2011, 23, 3987-3992.

41. Mo, Z.; Liao, S.; Zheng, Y., Fu, Z. Preparation of nitrogen-doped carbon nanotube arrays and their catalysis towards cathodic oxygen reduction in acidic and alkaline media. Carbon 2012, 50, 2620. 
42. Kothandaraman, R.; Nallathambi, V.; Artyushkova, K.; Barton, S.C. Non-Precious Oxygen Reduction Catalysts Prepared by High-Pressure Pyrolysis for Low-Temperature Fuel Cell. Appl. Catal. B 2009, 92, 209-216.

43. Herzog, B.; Herein, D.; Schlögl, R. In situ X-ray Powder Diffraction Analysis of the Microstructure of Activated Iron Catalysts for Ammonia Synthesis. Appl. Catal. A: General 1996, $141,71-104$.

44. Lafèvre, M.; Dodelet, J.P.; Bertrand, P. Molecular Oxygen Reduction in PEM Fuel Cells: Evidence for the Simultaneous Presence of Two Active Sites in Fe-Based Catalysts. J. Phys. Chem. B 2002, 106, 8705-8713.

45. Bailey, L.D.; Ttrudeau, M.; Joly, A.; Schulz, R.; Lalande, G.; Guay, D.; Dodelet, J.P.; Graphitization and Particles Size Analysis of Pyrolyzed Cobalt Phthalocyanine/Carbon Catalysts for Oxygen Reduction in Fuel Cells. J. Mater. Res. 1994, 9, 3202-3209.

46. Gojković, S.Lj; Gupta, S; Savinell, R.F.; Heat-Treated Iron(III) Tetramethoxyphenyl Porphyrin Chloride Supported on High-Area Carbon as an Electrcatalysts for Oxygen Reduction. J. Electroanal. Chem. 1999, 462, 63-72.

47. Subramanian, N.P.; Li, X; Nallathambi, V; Kumaraguru, S.W.; Mercado, H.C.; Wu, G.; Lee, J.W.; Popov, B.N.; Nitrogen-Modified Carbon-Based Catalysts for Oxygen Reduction Reaction in Polymer Electrolyte Membrane Fuel Cells. J. Power Sources 2009, 188, 38-44.

48. Hummers, W,S,; Offeman,R.E.; Preparation of Graphitic Oxide. J. Am. Chem. Soc. 1958, $80,1339$. 


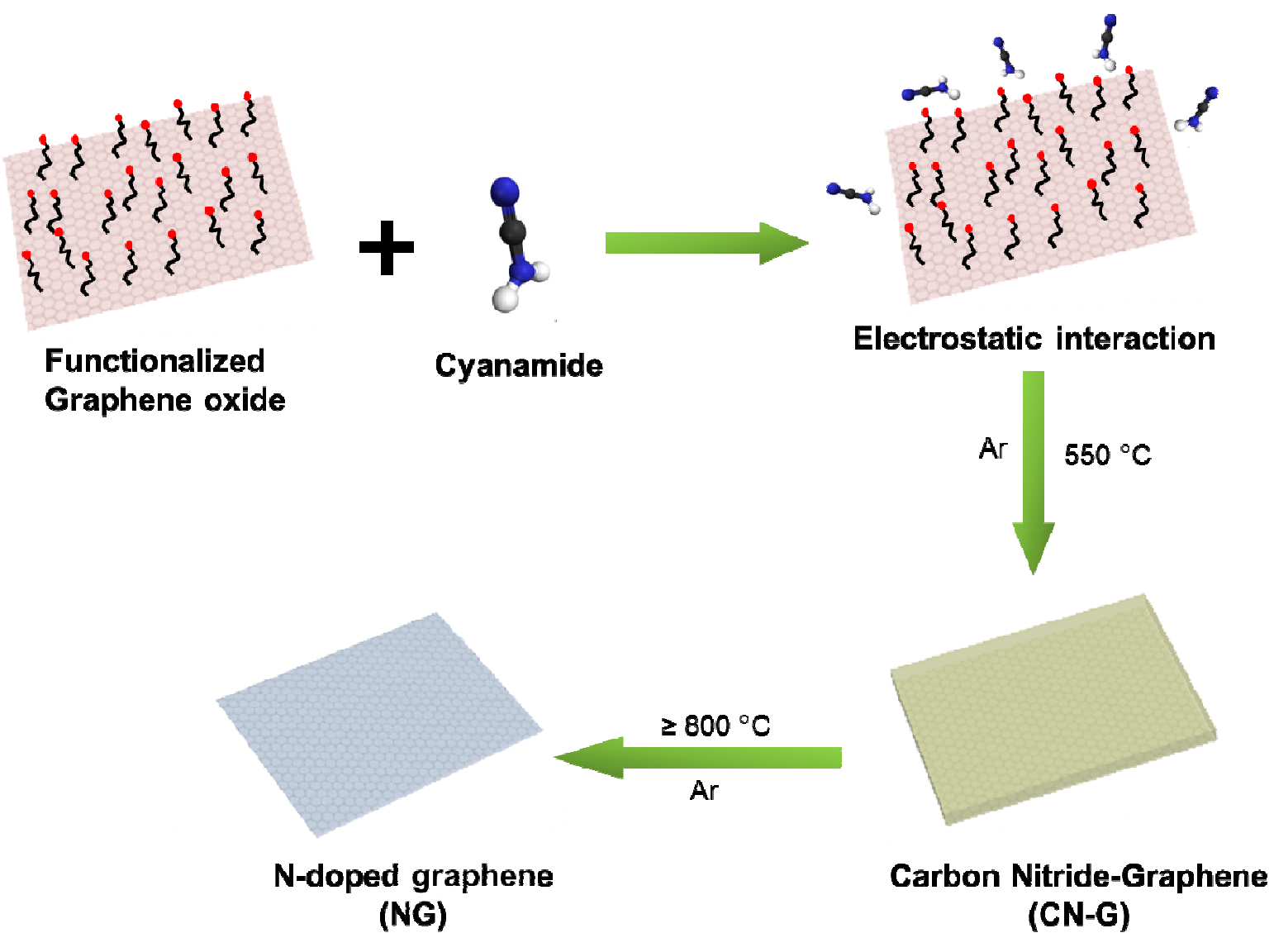

Figure 1: Preparation of NG for ORR. 

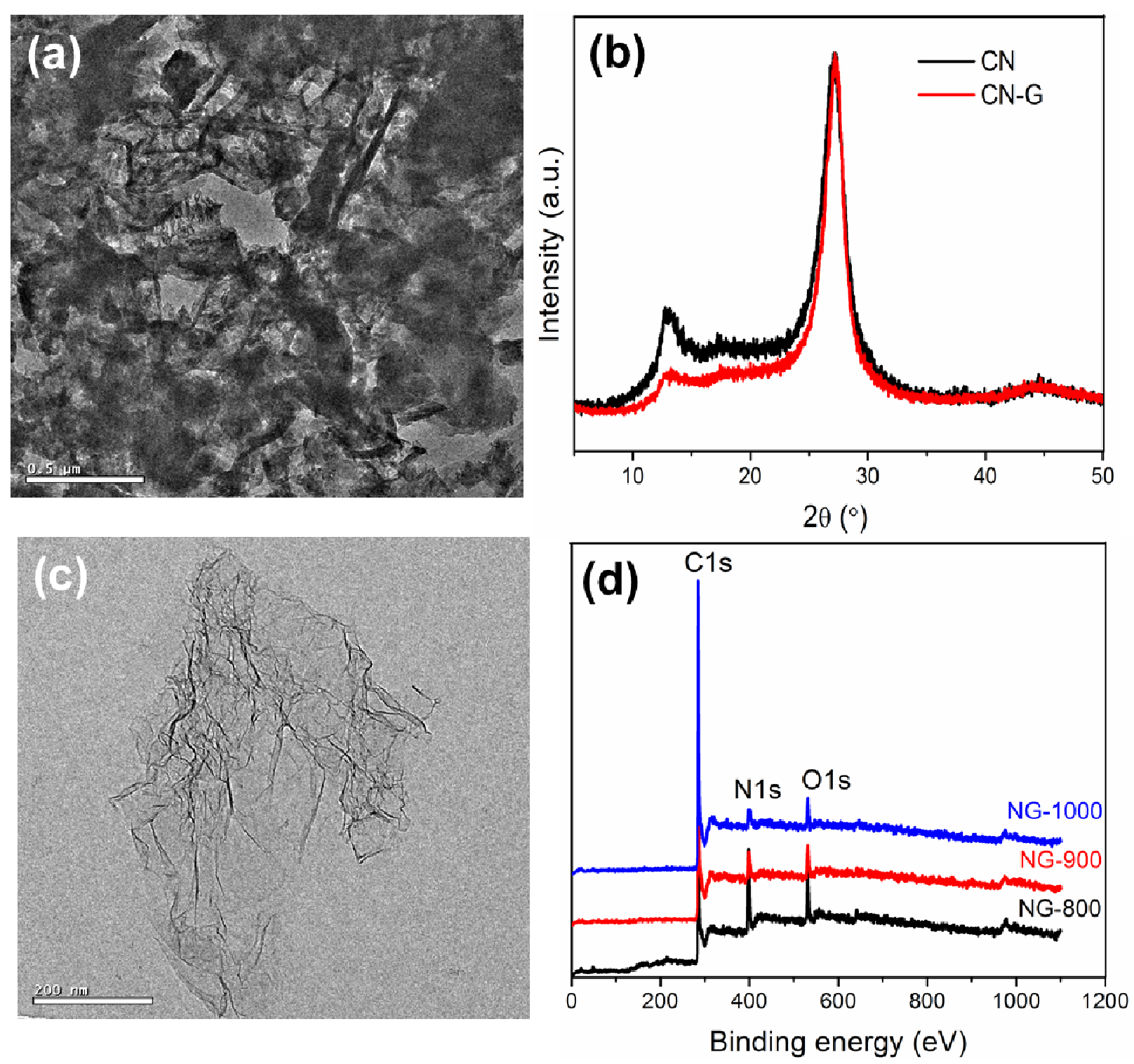

Figure 2: (a) TEM image and (b) XRD pattern of $\mathrm{CN}$ and $\mathrm{CN}-\mathrm{G}$ composite, (c) TEM image of CN-G composite after pyrolyzing at $900{ }^{\circ} \mathrm{C}$ (i.e. NG-900) and (d) XPS survey of NG samples 

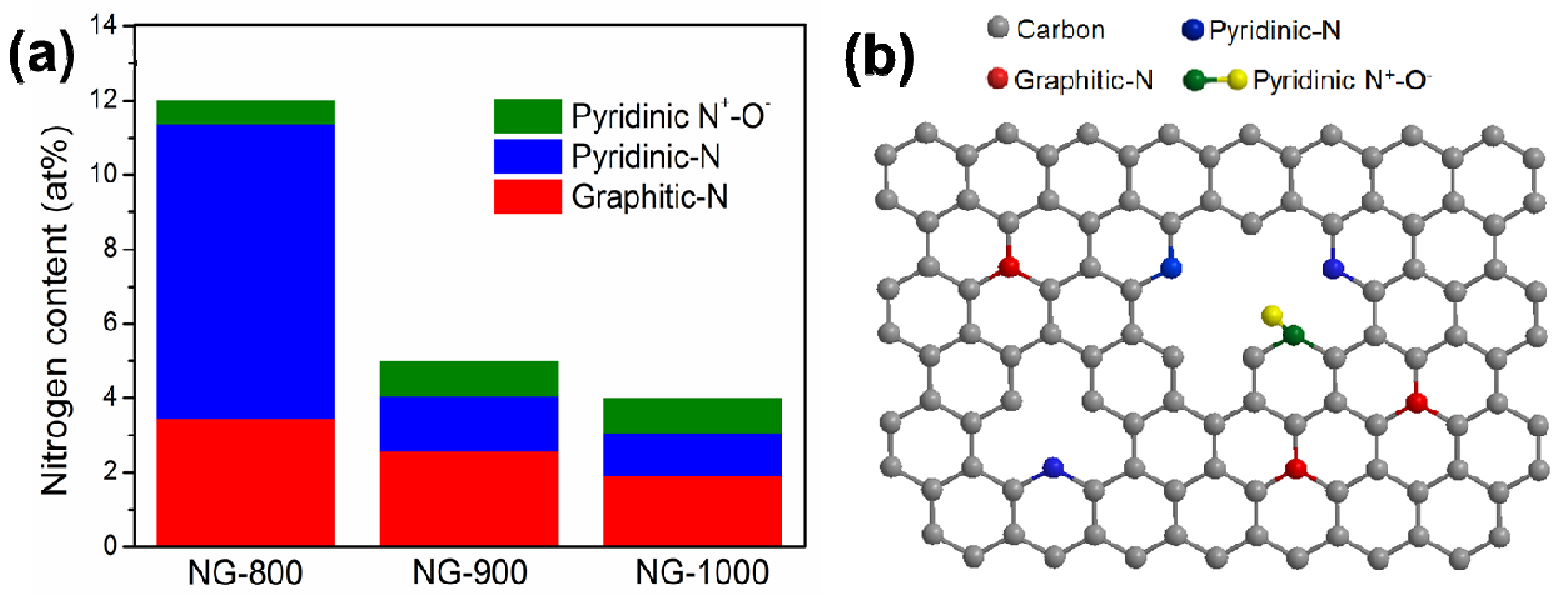

Figure 3: (a) The content of three types of nitrogen in NG, (b) Schematic representation of NG. 
1

2

3

4

5

6

7

8

9

10

11

12

13

14

15

16

17

18

19

20

21

22

23

24

25

26

27

28

29

30

31

32

33

34

35

36

37

38

39

40

41

42

43

44

45

46

47

48

49

50

51

52

53

54

55

56

57

58

59

60
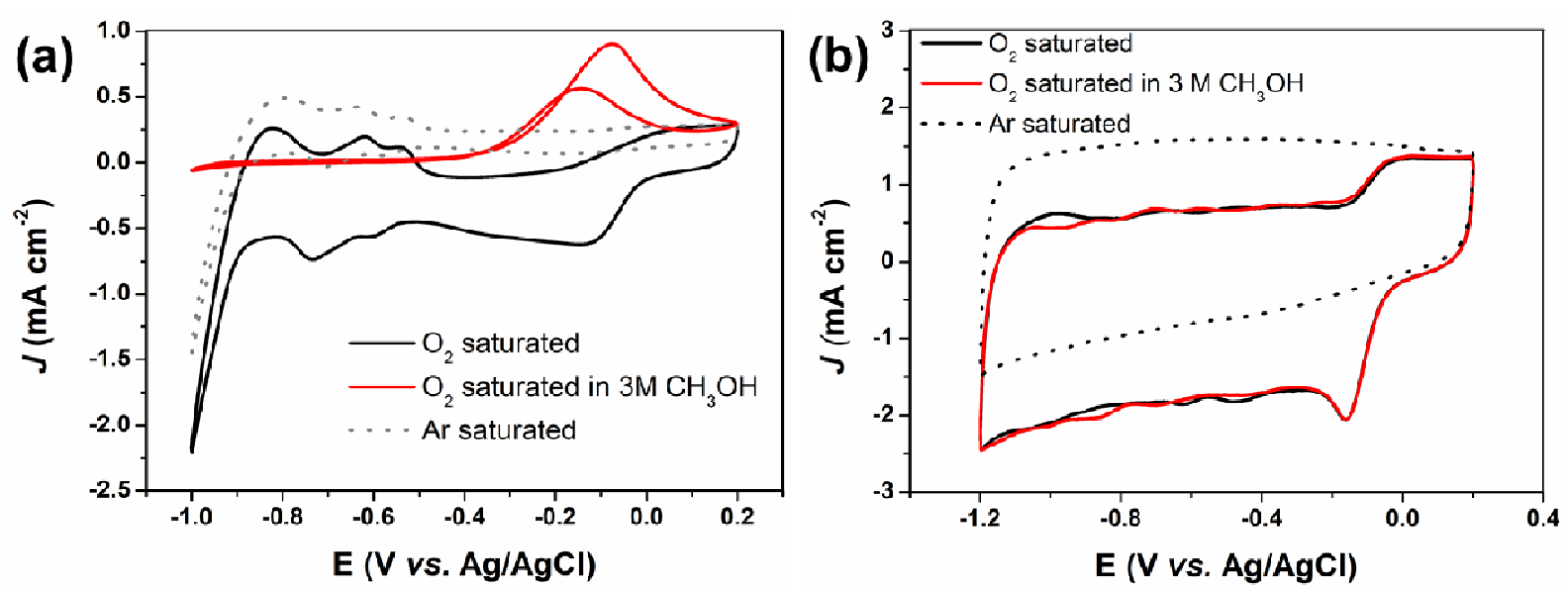

Figure 4: Cyclic voltammograms of (a) NG-900 and (b) $\mathrm{Pt} / \mathrm{C}$ at a scan rate of $100 \mathrm{mV} \mathrm{cm}^{-1}$ in $\mathrm{O}_{2}$ or Ar-saturated $0.1 \mathrm{M} \mathrm{KOH}$ solutions as well as $\mathrm{O}_{2}$-saturated $0.1 \mathrm{M} \mathrm{KOH}$ solution with $3 \mathrm{M}$ $\mathrm{CH}_{3} \mathrm{OH}$. 
(a)
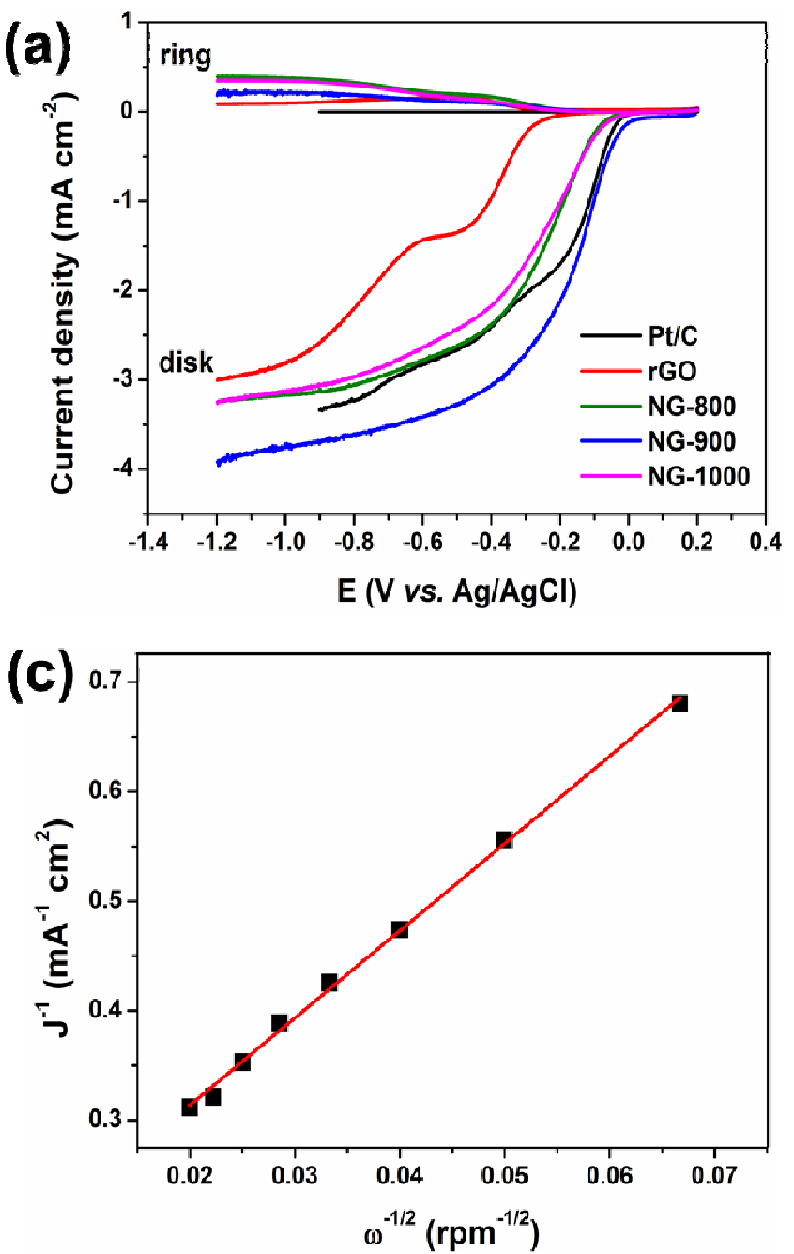

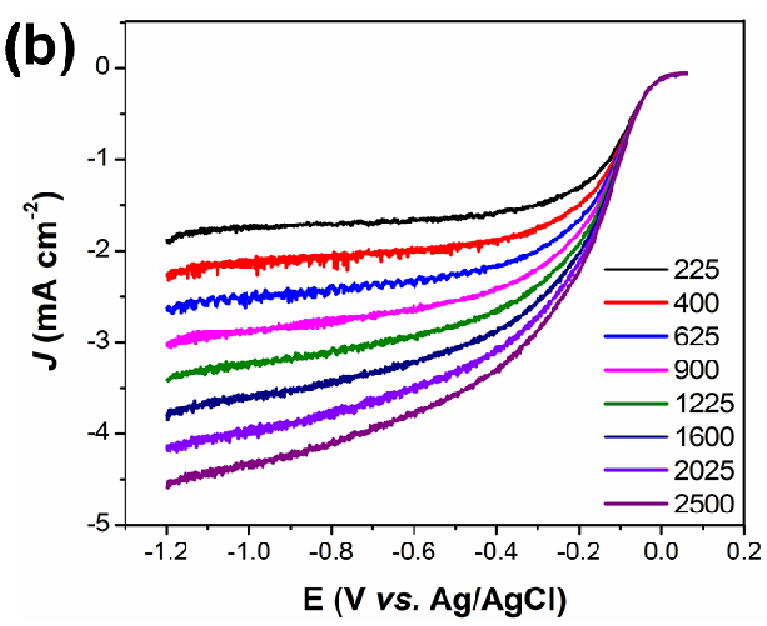

(d)

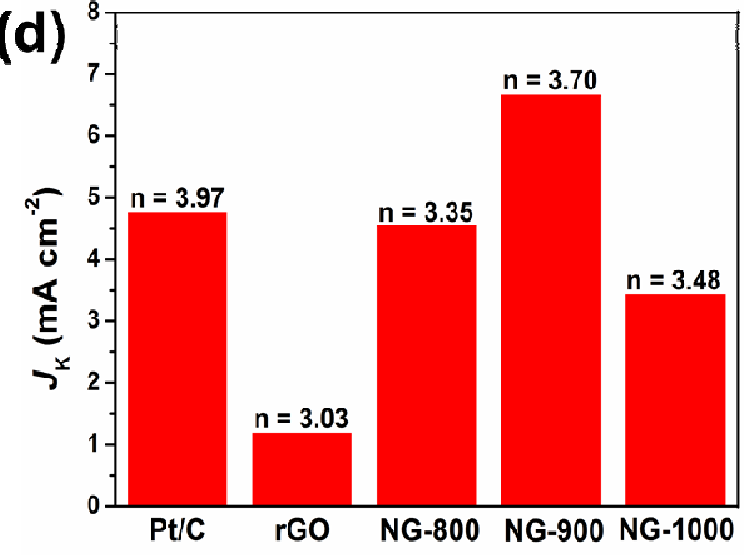

Figure 5: (a) RRDE voltammetric response for the $\mathrm{ORR}$ in $\mathrm{O}_{2}$ saturated $0.1 \mathrm{M} \mathrm{KOH}$ at a scan rate of $10 \mathrm{mVs}^{-1}$. The electrode rotation rate was $1600 \mathrm{rpm}$ and the Pt ring electrode was polarized at $0.5 \mathrm{~V}$; (b) RDE voltammograms recorded for NG-900 supported on a GC electrode in an $\mathrm{O}_{2^{-}}$ saturated $0.1 \mathrm{M} \mathrm{KOH}$ solution at a scan rate of $10 \mathrm{mVs}^{-1}$ and different rotation rates; (c) Koutecky-Levich plot of $J^{1} v s . \omega^{-1 / 2}$ at $-0.4 \mathrm{~V}$ obtained from (b); and (d) Electrochemical activity given as the kinetic-limiting current density $\left(J_{\mathrm{K}}\right)$ at $-0.4 \mathrm{~V}$ for $\mathrm{Pt} / \mathrm{C}, \mathrm{rGO}$, and all three $\mathrm{NG}$ electrodes. 

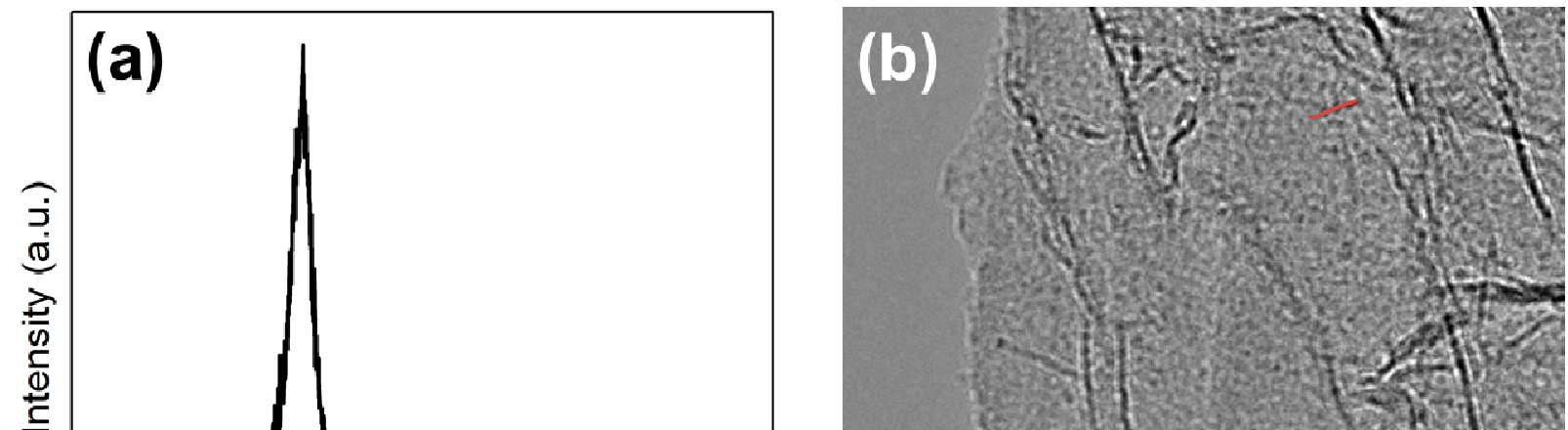
(a)

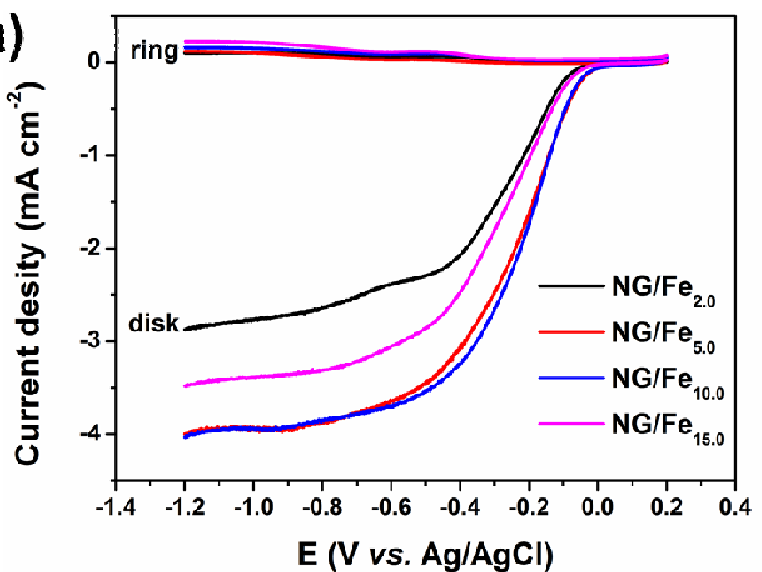

(c)

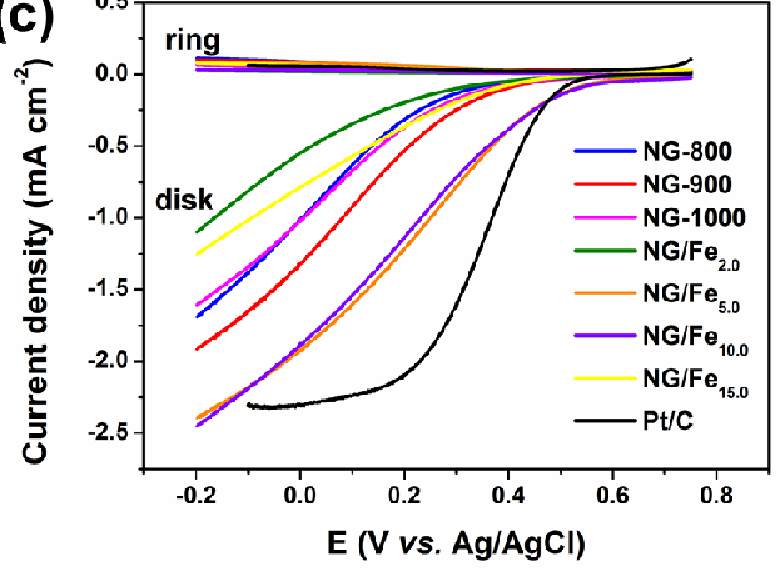

(b)

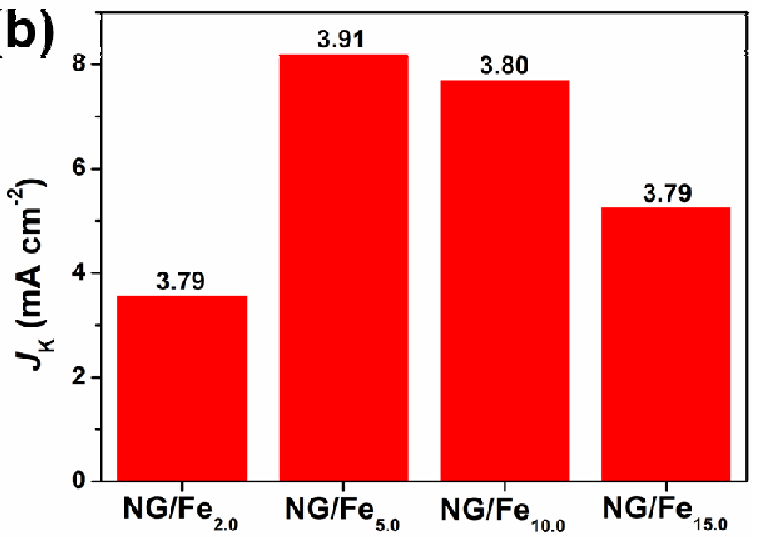

(d)

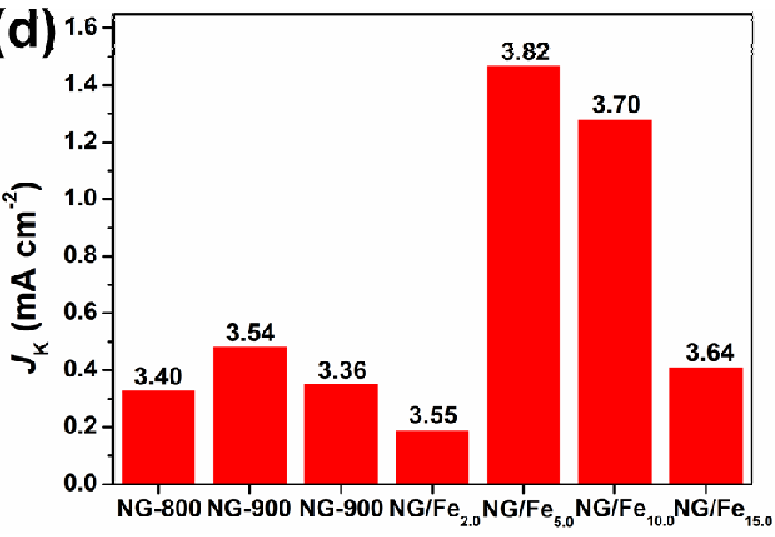

Figure 7: (a) RRDE polarization curves of $\mathrm{NG} / \mathrm{Fe}_{\mathrm{x}}$ samples in $\mathrm{O}_{2}$ saturated $0.1 \mathrm{M} \mathrm{KOH}$ at a scan rate of $10 \mathrm{mVs}^{-1}$ and $1600 \mathrm{rpm}$ electrode rotation rate; (b) Electrochemical activity given as the kinetic-limiting current density $\left(J_{\mathrm{K}}\right)$ of the $\mathrm{NG} / \mathrm{Fe}_{\mathrm{x}}$ series supported on GC electrodes at $-0.4 \mathrm{~V}$; (c) RRDE curves of $\mathrm{NG}$ and $\mathrm{NG} / \mathrm{Fe}_{\mathrm{x}}$ series in $\mathrm{O}_{2}$-saturated $0.5 \mathrm{M} \mathrm{H}_{2} \mathrm{SO}_{4}$ at a scan rate of $10 \mathrm{mVs}^{-}$ ${ }^{1}$ and $1600 \mathrm{rpm}$ electrode rotation rate; and (d) Electrochemical activity given as the kineticlimiting current density $\left(J_{\mathrm{K}}\right)$ of $\mathrm{NG}$ and $\mathrm{NG} / \mathrm{Fe}_{\mathrm{x}}$ series supported on $\mathrm{GC}$ electrodes at $0.2 \mathrm{~V}$. The electron transferred number (n) in (b) and (d) was obtained from RRDE. 
(a)

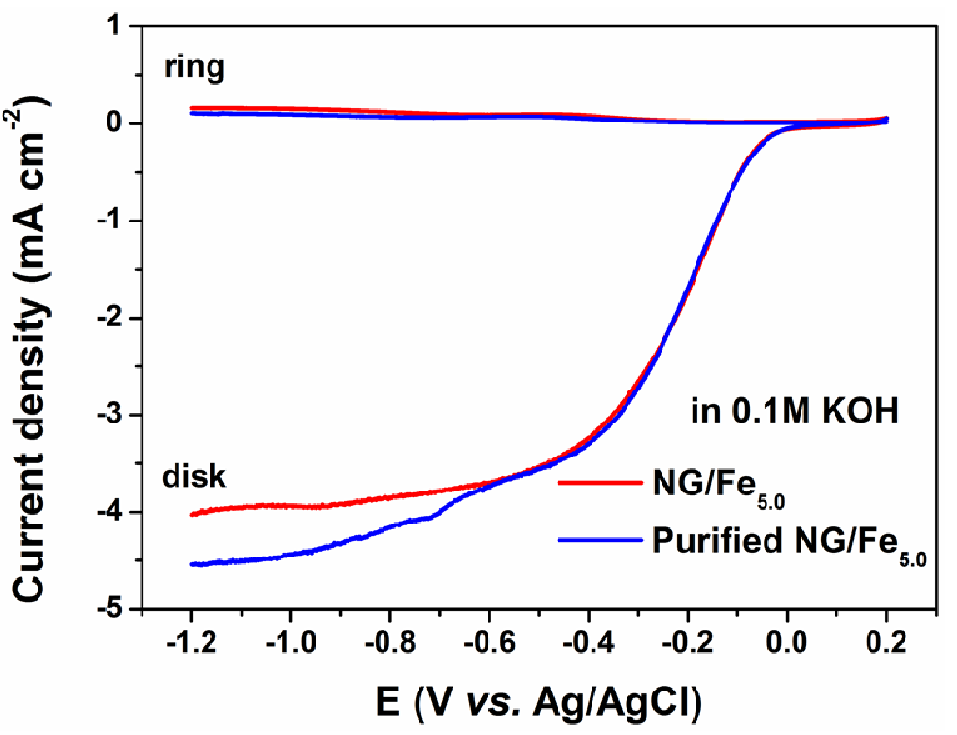

(b)

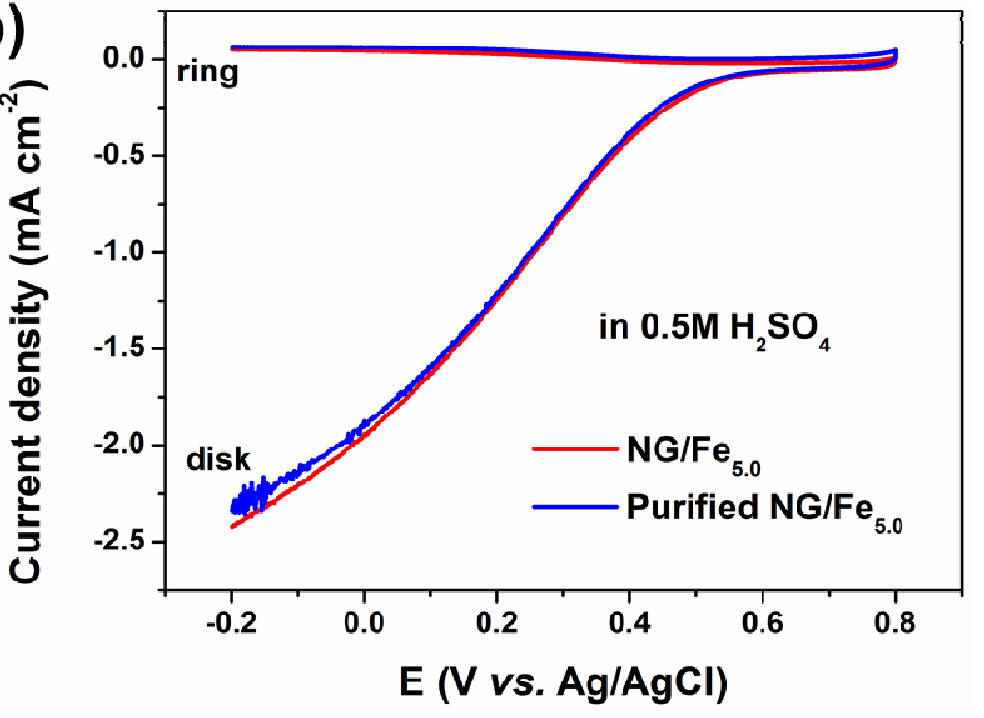

Figure 8: RRDE polarization curves of purified and unpurified $\mathrm{NG} / \mathrm{Fe}_{5.0}$ in $\mathrm{O}_{2}$-saturated (a) $0.1 \mathrm{M}$ $\mathrm{KOH}$ and (b) $0.5 \mathrm{M} \mathrm{H}_{2} \mathrm{SO}_{4}$ solution at a rotation rate of $1600 \mathrm{rpm}$. 


\section{ToC image}

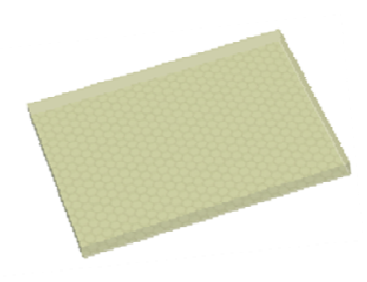

Carbon Nitride-Graphene (CN-G)

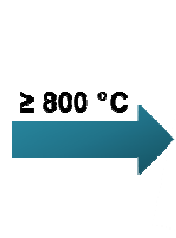

N-doped Graphene

(NG)

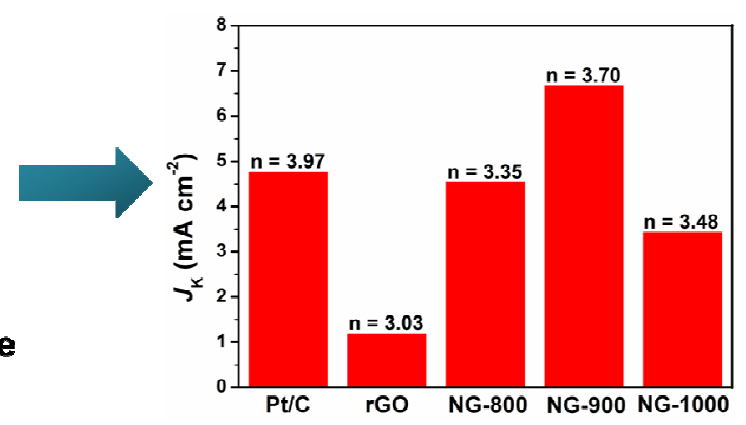

17 